\title{
Assessment of anxiety and self-esteem experienced by women during pregnancy*
}

Avaliação da ansiedade e autoestima vivenciada por mulheres durante a gravidez

Evaluación de la ansiedad y la autoestima que experimentan las mujeres durante el embarazo

\section{Nathália Gianini Nery', Patrícia Mônica Ribeiro ${ }^{\mathrm{II}}$, Eliana Peres Rocha Carvalho Leite ${ }^{\mathrm{III}}$, Denismar Alves Nogueira ${ }^{\mathrm{IV}}$, Sérgio Valverde Marques dos Santos ${ }^{\mathrm{v}}$, Fábio de Souza Terra ${ }^{\mathrm{VI}}$}

\begin{abstract}
Objective: analyze the relationship between feelings of anxiety and levels of self-esteem experienced by women during pregnancy. Method: cross-sectional study carried out with 201 pregnant women in a city in the south of Minas Gerais, Brazil, between 2019 and 2020. For data collection, the questionnaire on sociodemographic characterization, lifestyle and information on pregnancy and important events in life was applied. Anxiety and Depression (anxiety subscale) and Rosenberg's Self-Esteem Scale. For data analysis, descriptive and inferential statistics were used, through Pearson's Chi-square, Fisher's Exact and logistic regression tests. Results: the variables change in mood and the influence of physical change during pregnancy on women's lives are associated with anxiety. As for selfesteem, no independent variable was statistically associated. Pregnant women with anxiety are three times more likely to have medium/low self-esteem. Conclusion: many women changed anxiety and self-esteem during pregnancy. Professional follow-up is important to monitor and prevent complications.
\end{abstract}

Descriptors: Pregnancy; Women's Health; Anxiety; Self Concept; Nursing

Resumo: Objetivo: analisar a relação entre sentimentos de ansiedade e níveis de autoestima vivenciados por mulheres durante a gravidez. Método: estudo transversal realizado com 201 gestantes de um município do Sul de Minas Gerais, Brasil, entre 2019 e 2020. Para a coleta de dados, foi utilizado o questionário de caracterização sociodemográfica, estilo de vida e informações sobre gravidez e eventos importantes da vida. Ansiedade e Depressão (subescala de ansiedade) e Escala de Autoestima de Rosenberg. Para a análise dos dados, utilizou-se a estatística descritiva e inferencial, por meio dos testes Qui-quadrado de Pearson, Exato de Fisher e regressão

\footnotetext{
${ }^{\text {I }}$ Master in Nursing from Unifal-MG; Alfenas, Minas Gerais, Brazil. Email: nathaliagianininery@gmail.com Orcid: https://orcid.org/0000-0002-6148-0613 II Ph.D. Professor in Nursing at Unifal-MG; Alfenas, Minas Gerais, Brazil. Email: patrícia.ribeiro@unifal-mg.edu.br Orcid: https://orcid.org/0000-0001-6713-6728 III PhD Professor in Nursing at Unifal-MG; Alfenas, Minas Gerais, Brazil. Email: eprcl@yahoo.com.br Orcid: https://orcid.org/0000-0002-4506-8899 IV PhD Professor in Statistics at Unifal-MG; Alfenas, Minas Gerais, Brazil. Email: denisnog@gmail.com Orcid: https://orcid.org/0000-0003-2285-8764 V PhD Professor in Nursing at UEMG-MG; Alfenas, Minas Gerais, Brazil. Email: sergiovalverdemarques@hotmail.com Orcid: https://orcid.org/0000-00019412-9515

VI PhD Professor in Nursing at Unifal-MG; Alfenas, Minas Gerais, Brazil. Email: fabio.terra@unifal-mg.edu.br Orcid: https://orcid.org/0000-0001-8322-3039

* Extracted from the dissertation "Assessment of anxiety and self-esteem in women during pregnancy", Postgraduate Program in Nursing, Federal University of Alfenas-MG, Minas Gerais, Brazil, 2020.
} 
logística. Resultados: as variáveis mudança de humor e a influência da mudança física durante a gravidez na vida das mulheres estão associadas à ansiedade. Quanto à autoestima, nenhuma variável independente se associou estatisticamente. Mulheres grávidas com ansiedade têm três vezes mais chances de ter autoestima média / baixa. Conclusão: muitas mulheres alteraram a ansiedade e a autoestima durante a gravidez. $\mathrm{O}$ acompanhamento profissional é importante para monitorar e prevenir complicações.

Descritores: Gravidez; Saúde da Mulher; Ansiedade; Autoimagem; Enfermagem

Resumen: Objetivo: analizar la relación entre los sentimientos de ansiedad y los niveles de autoestima que experimentan las mujeres durante el embarazo. Método: estudio transversal realizado con 201 gestantes en un municipio del sur de Minas Gerais, Brasil, entre 2019 y 2020. Para la recolección de datos se utilizó un cuestionario de caracterización sociodemográfica, estilo de vida e información sobre embarazo y eventos importantes de la vida. Se aplicó la Escala de Ansiedad y Depresión (subescala de ansiedad) y la Escala de Autoestima de Rosenberg. Para el análisis de los datos se utilizó estadística descriptiva e inferencial, mediante pruebas de Chi-cuadrado de Pearson, Exacto de Fisher y regresión logística. Resultados: las variables cambios de humor y la influencia del cambio físico durante el embarazo en la vida de las mujeres están asociadas a la ansiedad. En cuanto a la autoestima, no se asoció estadísticamente ninguna variable independiente. Las mujeres embarazadas con ansiedad tienen tres veces más probabilidades de tener una autoestima media / baja. Conclusión: muchas mujeres cambiaron su ansiedad y autoestima durante el embarazo. El seguimiento profesional es importante para controlar y prevenir complicaciones.

Descriptores: El Embarazo; La Salud de la Mujer; Ansiedad; Autoimagen; Enfermería

\section{Introduction}

Mental disorders are becoming increasingly more challenging for public healthcare systems worldwide, growing significantly in recent years. In women, these disorders are even more significant, since they are twice as likely to develop some form of mental illness when compared to men. This fact becomes more evident during pregnancy, when there is a need for more attention focused on pregnant women. ${ }^{1-2}$

Pregnancy is a moment of intense changes for women, including physical and hormonal changes in their bodies, in order to provide conditions for adequate fetal growth and development in balance with the maternal organism. ${ }^{3-4}$ Women are also exposed to emotional risks during this maternal period, such as changes in self-esteem and the presence of anxiety, in addition to pathological risks, such as postpartum depression. ${ }^{5}$ 
3 | Nery NG, Ribeiro PM, Leite EPRC, Nogueira DA, Santos SVM, Terra FS

Emotional changes can be noticed during pregnancy, such as the emergence of anxiety, stress, depression, and changes in the level of self-esteem. These changes stand out starting from the transition stage experienced, the changes resulting from the gestation phase, the bond to be established with the child, and the breastfeeding process. ${ }^{6}$

Anxiety and self-esteem may be interlinked since low self-esteem can generate a feeling of vulnerability toward obstacles and thus result in an inability to solve problems. Therefore, women can experience anxiety symptoms when dealing with the adversities of life during pregnancy. As a consequence, pregnant women may experience negative feelings toward themselves and the environment they are a part of, which may lead to a decrease in their level of self-esteem and, thus, the emergence of anxiety at a more dangerous level. ${ }^{7}$

In this context, anxiety is considered one of the main risk factors for the healthy development of pregnancy since the presence of pathological anxiety can compromise the health of the fetus. Thus, anxiety can lead to negative outcomes, such as prematurity, low birth weight, lower APGAR scores, impairment of fetal growth, and long-lasting effects on physical and psychological development, including changes in self-esteem, and the probable obstetric complications, such as vaginal bleeding, the threat of abortion, and postpartum depression. ${ }^{8}$

Given the above, the need to carry out studies on this topic (anxiety and self-esteem during pregnancy) is justified, as it is extremely important to know about emotional changes during pregnancy in order to promote public policies aimed at pregnant women. In addition, the results found in this investigation may contribute to scientific knowledge, especially in the field of nursing, to assist in the development of care protocols, in order to promote a more comprehensive and qualified care for pregnant women.

Thus, the following guiding question was drawn up for this study: "Do women exhibit symptoms of anxiety and altered self-esteem during the gestation period?” Therefore, this study 
aimed to analyze the relationship between feelings of anxiety and the levels of self-esteem experienced by women during pregnancy.

\section{Method}

\section{Study design}

A cross-sectional, descriptive-analytical study, carried out with pregnant women using the urban Family Health Strategy (ESF).

\section{Research scenario}

The study was carried out in an ESF of a city located in the south of Minas Gerais, Brazil. In this city, there are $16 \mathrm{ESF}$ centers, all of which offer prenatal care to pregnant women, with alternate prenatal consultations provided by doctors and nurses and within the Brazilian Unified Health System (SUS).

\section{Participants and selection criteria}

The study population consisted of all women who were in the gestational period and who attended prenatal consultations at the ESF in that municipality. Thus, the population consisted of 230 pregnant women invited to participate in the research. All pregnant women registered in the ESF were invited to participate in the study. Therefore, it was not necessary to calculate the sample.

The following inclusion criteria were adopted to select the participants: to be aged 18 or over, to be in the gestation period, and to be assisted through prenatal appointments in the urban ESF center of the city where the study is being carried out. Thus, the study sample consisted of 201 women in the gestation period, due to a significant number of participants who refused to contribute to the study. 
5 | Nery NG, Ribeiro PM, Leite EPRC, Nogueira DA, Santos SVM, Terra FS

\section{Data Sources/Measurement}

Three instruments were used for data collection. The first was a semi-structured questionnaire with 26 questions, developed by the researchers, to evaluate data on sociodemographic profiling, life habits, chronic disease, pregnancy, and outstanding events in the life of pregnant women, with its content based on national and international literature. The present instrument was submitted to a refinement process, with the evaluation of five judges, and then a pilot test was carried out, to verify its effectiveness and applicability.

The second instrument used was one of the Hospital Anxiety and Depression Scale's subscales, to evaluate the participants' level of anxiety. This Scale was developed in 1983, and it was translated and validated into Portuguese in 1998. It consists of 14 items, which are fragmented into anxiety and depression subscales, of which seven are focused on evaluating anxiety and another seven on depression. Each of its items can be scored from zero to three, composing a maximum score of 21 points for each subscale. The cut-off points are: "without anxiety" from 0 to 8 and "with anxiety" $\geq 9$. The anxiety subscale was the only one used in the present investigation. ${ }^{9}$

The third instrument used was the Rosenberg Self-Esteem Scale, which was used in this study to evaluate the self-esteem levels experienced by the study participants. It was developed in English in 1965, and it was translated and validated into Portuguese in 2001. This scale consists of ten items: five alternatives refer to a positive view of oneself, while the other alternatives refer to a self-deprecating view. The response options are of the four-point Likert type. For self-esteem classification, all items are added together amounting to a single value for the scale, and its possible range is from 10 to 40 points, where scores above 30 points can be classified as satisfactory or high, scores ranging between 20 to 30 points can be classified as medium, and scores below 20 points can be classified as unsatisfactory or low. ${ }^{10}$ 
Assessment of anxiety and self-esteem experienced by women during pregnancy $\mid 6$

\section{Data collect}

Data collection was carried out between December 2019 and January 2020, through interviews, during the prenatal appointments attended by pregnant women at the ESF center, without interfering with the center's activities and dynamics. The survey objectives were presented to the women and their voluntary collaboration was requested. Afterward, the instruments were presented and data collection was initiated. It is worth mentioning that the instruments were filled out by the researchers, in an interview format, according to the pregnant women's answers, since they could experience difficulties filling out the forms themselves.

\section{Data analysis}

The data collected through the instruments were recorded into an MS-Excel spreadsheet version 2010, for database preparation. Afterward, the data were transferred to the IBM Statistical Package for the Social Sciences version 20.0, for descriptive and inferential analysis. The Cronbach's Alpha Coefficient was used to check the scales' internal consistency.

Pearson's Chi-square and Fisher's Exact tests were used to verify the existence of an association between anxiety and self-esteem variables, and the association between women's feelings of anxiety with levels of self-esteem during the gestation period. The significance level of $5 \%$ was accepted for all analyses. Then, the odds ratio was estimated and the Logistic Regression model was used, through the Forward Stepwise selection method, of the independent variables with anxiety and self-esteem, with a 95\% confidence interval.

Given the nature of the dummy variables, we have chosen to use logistic regression to carry out the regression analyses. The dependent variables of the study were 'anxiety' and 'selfesteem', both presented in a dichotomous way. The selection of independent variables, which were also dichotomized, was performed using the Bayer method. ${ }^{11}$ 
7 | Nery NG, Ribeiro PM, Leite EPRC, Nogueira DA, Santos SVM, Terra FS

Thus, all independent variables were included in the analyses. Possible combinations of variables were selected until those with an adjusted model had been reached. For the final model obtained, the corresponding odds ratio of the parameters was calculated.

\section{Ethical aspects}

Based on the National Health Council Resolution 466/2012, which deals with research involving human beings, this research was evaluated and approved by the Research Ethics Committee, according to legal opinion nº 3.398 .379 .

\section{Results}

When analyzing the data on sociodemographic profiling, life habits, and chronic diseases affecting pregnant women, it was found that the average age among the participants was 26.2 years. Most of them were married or lived with a partner $(60.2 \%)$, most were Catholic $(62.7 \%)$, almost all of them had up to 2 children (95\%), their average monthly family income was of 1736.74 reais (approximately 300 dollars) and part of them had completed high school (47.8\%). It was also found that most of the women interviewed did not consume alcoholic beverages (95.0\%), did not use illicit drugs (96.5\%), did not smoke (90.5\%), did not practice physical activity (76.1\%), did not have other chronic diseases (89.1\%) and used continuous and/or daily medication (58.7\%).

Regarding the pregnancy data, it was found that most pregnant women did not plan pregnancy $(57.7 \%)$, most of them attended habitual-risk prenatal care appointments $(83.1 \%)$, for some it was not their first delivery $(53.7 \%)$, and part of them had a gestational age ranging between 14 and 27 weeks (2nd trimester) (46.8\%). Most of these women had no concerns (58.2\%) and no pregnancy issues (85.6\%), some of them experienced mood swings $(61.7 \%)$, and some of them found that the physical changes experienced by them during pregnancy influenced their lives (65.2\%). The 
pregnant women also stated that they had a good relationship with the child's father $(43.8 \%)$ and that they will receive assistance to take care of the child (87.1\%).

Regarding remarkable life events, most pregnant women denied having experienced any event in the last twelve months (73.6\%). The most remarkable event was the loss (death) of a loved one (56.6\%) for those who stated having experienced any event within that timeframe. When evaluating the feelings of anxiety experienced by pregnant women, it was possible to verify that $48.2 \%$ of them had felt anxiety (Table 1). Regarding internal consistency, the Cronbach's Alpha Coefficient was 0,804, which indicates satisfactory reliability and homogeneity.

Table 1 - Distribution of women in the gestation period according to the anxiety classification. Minas Gerais, Brazil. 2019/2020. (n=201)

\begin{tabular}{lccc}
\hline \multicolumn{1}{c}{ Anxiety classification } & F & \% & Cronbach's Alpha \\
\hline Without anxiety & 101 & 51.8 & 0.804 \\
With anxiety & 100 & 48.2 & \\
Total & 201 & 100 & 0.846 \\
\hline
\end{tabular}

After checking possible associations of anxiety with all independent variables, it was found that the variables "mood swings" and "influence of physical change during pregnancy on women's lives" had an association with anxiety $(\mathrm{p}<0.05)$. Therefore, pregnant women who claimed to have experienced mood swings were approximately 2.5 times more likely to have experienced feelings of anxiety, as well as those who denied that the physical changes during pregnancy had influenced their lives were almost 2 times more likely to develop anxiety (Table 2).

Table 2 - Univariate analysis of the factors associated with the anxiety experienced by women during the gestation period. Minas Gerais, Brazil, 2019/2020. ( $n=201)$

\begin{tabular}{|c|c|c|c|c|c|}
\hline Variables & $\begin{array}{c}\text { Without } \\
\text { anxiety } \\
n(\%)\end{array}$ & $\begin{array}{l}\text { With anxiety } \\
n(\%)\end{array}$ & p-value* & $\mathrm{OR}^{\dagger}$ & $\mathrm{CI}^{\ddagger} \mathbf{9 5 \%}$ \\
\hline \multicolumn{6}{|l|}{ Mood swings } \\
\hline No & $49(48.5)$ & $28(28.0)$ & \multirow{2}{*}{$0.003^{*}$} & 1 & \\
\hline Yes & $52(51.5)$ & $72(72.0)$ & & 2.423 & $1.349-4.352$ \\
\hline $\begin{array}{l}\text { Influence of physical changes during } \\
\text { pregnancy on women's lives }\end{array}$ & & & & & \\
\hline
\end{tabular}


9 | Nery NG, Ribeiro PM, Leite EPRC, Nogueira DA, Santos SVM, Terra FS

\begin{tabular}{|c|c|c|c|c|c|}
\hline No & $73(72.3)$ & $58(58.0)$ & \multirow{2}{*}{$0.034^{*}$} & 1.888 & \multirow{2}{*}{$1.047-3.404$} \\
\hline Yes & $28(27.7)$ & $42(42.0)$ & & 1 & \\
\hline
\end{tabular}

When analyzing the parameters of all independent variables with anxiety, using the logistic regression model, it was found that the variable "mood swings" presented statistical association $(\mathrm{p}=0.003)$, resulting in a final adjusted model. Thus, the model determined that women in the gestation period who experienced mood swings were 2.5 times more likely to experience feelings of anxiety.

Upon evaluating the distribution of women in the gestation period, it was found that most of them had experienced medium levels of self-esteem (Table 3) according to the selfesteem classification. It was also found that the Cronbach's Alfa coefficient value was 0.846 , which demonstrates the instrument's homogeneity and reliability.

Table 3 - Distribution of women in the gestation period according to the self-esteem classification. Minas Gerais, Brazil, 2019/2020 (n=201)

\begin{tabular}{lccc}
\hline \multicolumn{1}{c}{ Self-esteem classification } & F & \% & Cronbach's Alpha \\
\hline High self-esteem & 35 & 17.4 & \\
Medium self-esteem & 163 & 81.1 & 0.846 \\
Low self-esteem & 3 & 1.5 & \\
\hline Total & 201 & 100 & 0.846 \\
\hline
\end{tabular}

In the univariate analysis of all the independent variables of the questionnaire with selfesteem, it was found that these variables were not significantly associated with the self-esteem levels experienced by pregnant women. It is important to emphasize that after analyzing the parameters of all these independent variables with self-esteem through the logistic regression model, it was found that no variable remained in the final model $(\mathrm{p}>0.05)$.

In the univariate analysis of the feelings of anxiety with the levels of self-esteem experienced by pregnant women, a significant association between these variables was found. 
Thus, it was found that women in the gestation period who experienced anxiety were almost four times more likely to experience medium/low levels of self-esteem (Table 4).

Table 4 - Univariate analysis of the association of the anxiety variable with the self-esteem variable of women in the gestation period. Alfenas, MG, Brazil, 2019/2020. ( $n=201)$

\begin{tabular}{lccccc}
\hline Variables & $\begin{array}{c}\text { High self-esteem } \\
\mathrm{n}(\%)\end{array}$ & $\begin{array}{c}\text { Medium/low self-esteem } \\
\mathbf{n}(\%)\end{array}$ & $\mathrm{p}^{\text {-value* }}$ & $\mathrm{OR}^{+}$ & $\mathrm{CI}^{\ddagger} \mathbf{9 5 \%}$ \\
\hline Anxiety & & & & & \\
No & $26(25.7)$ & $75(74.3)$ & $0.002^{*}$ & 1 & \\
Yes & $09(9.0)$ & $91(91.0)$ & & 3.505 & $1.548-7.937$ \\
\hline
\end{tabular}

${ }^{*}$ Pearson's Chi-square test application ${ }^{\dagger} \mathrm{OR}=$ Odds ratio ${ }^{*} \mathrm{CI}=$ Confidence Interval (inferior/superior)

\section{Discussion}

In the present study, it was found that women in the gestation period experienced feelings of anxiety and changes in self-esteem. Mental disorders are mostly found during pregnancy compared to the puerperal period. Therefore, the diagnosis and follow-up of these alterations are necessary during pregnancy. In light of this, in-depth knowledge of women's mental health during the gestation period is key in avoiding the risks of depression and anxiety during the puerperal period. ${ }^{12}$

In a survey carried out in the south of Minas Gerais with 209 pregnant women, it was noted that $26,8 \%$ of participants experienced feelings of anxiety. ${ }^{13}$ Other studies that evaluated the feelings of anxiety experienced by pregnant women indicated the presence of anxiety symptoms in pregnant women. ${ }^{14-15}$

Since pregnancy is considered by most women as something desirable, anxiety and depression should be uncommon symptoms, since pregnancy can be perceived as a vital, positive, and fulfilling experience for women. However, the literature reveals that one in four pregnant women experience mental disorders, and $48 \%$ of these women suffer from anxiety, with the presence of both positive and negative feelings. ${ }^{16}$ 
11 | Nery NG, Ribeiro PM, Leite EPRC, Nogueira DA, Santos SVM, Terra FS

It is important to emphasize that healthcare practitioners, including nurses, should perceive women as holistic beings throughout the gravidic-puerperal cycle, welcoming them with qualified listening and responsibility in the face of specificities, valuing the individualized context. The bond established between the practitioners and the pregnant women is beneficial, resulting in moments that will bring to light doubts, uncertainties, fears, among others. Thus, pregnant women can receive from the practitioners, among them the nurses, a better program for the promotion of their well-being during pregnancy. ${ }^{17}$

When verifying the association of anxiety with independent variables, it was found that pregnant women who had experienced mood swings during pregnancy and who did not believe that the physical changes during pregnancy influenced their lives were more likely to develop anxiety.

During the entire reproductive cycle in a woman's life, especially during pregnancy, hormonal changes occur in the neuroendocrine system. These changes can result in increased vulnerability and sensitivity to mood swings, directly influencing the occurrence of anxiety. ${ }^{18}$

The frequency of anxiety in pregnancy can also be explained by physical and mental changes resulting from this period and by the action of hormones in mood modulation. ${ }^{13-19}$ The feelings triggered in women during the gestation period can be positive and negative. These feelings, such as maternal stress, irritability, unhappiness, and sadness, are considered risk factors for mental disorders, including anxiety symptoms. ${ }^{20}$ It is worth mentioning that in this study, the main types of mood swings reported by pregnant women were feelings of irritation, instability, and sadness.

Pregnancy is mostly a unique and special moment, which can bring joy and a better quality of life to women. When pregnancy is welcomed, pregnant women are more receptive to the changes they will go through during this gestation period and will therefore acquire healthier habits, not allowing physical changes to negatively influence their lives. ${ }^{21}$

In contrast, the literature also states that women can experience substantial changes in body shape and weight during pregnancy in a short period of time during the three trimesters of 
Assessment of anxiety and self-esteem experienced by women during pregnancy | 12

pregnancy. All these physical changes in their bodies can influence their body image, leading to emotional changes, including anxiety. ${ }^{22}$

Regarding the levels of self-esteem, the literature points out that individuals experiencing high levels of self-esteem tend to be in good mood, emotionally balanced, and able to build good relationships. However, the lower the levels of self-esteem, the greater the association with bad feelings, depression, and anxiety, a fact that should not take place during pregnancy. ${ }^{23}$

In an investigation carried out with 12 adolescent pregnant women in the countryside of Minas Gerais, Brazil, it was found that all of them experienced low levels of self-esteem. ${ }^{24}$ In another survey carried out with 210 pregnant women assisted at the Health Center in Peru, it was found that $72.9 \%$ of them experienced high levels of self-esteem, and $25.7 \%$ of them experienced medium levels of self-esteem. ${ }^{25}$ Another study that evaluated the self-esteem levels experienced by 160 pregnant women during prenatal care in a hospital in Maranhão, found that pregnant women presented altered levels of self-esteem. ${ }^{26}$ This information corroborates with this study's results.

The anxiety and self-esteem variables presented statistical association, that is, women going through the gestation period while experiencing feelings of anxiety were more likely to present medium/low levels of self-esteem.

These results are similar to those found in other studies. A survey carried out in Paraíba, Brazil, found an association between the presence of anxiety at high levels and low levels of selfesteem. Thus, the higher the anxiety experienced by individuals, the lower their levels of selfesteem will be. ${ }^{19}$ Additionally, in an investigation carried out in Vietnam, a relationship between low levels of self-esteem and the presence of anxiety was found. Research carried out in the Netherlands and Germany also showed that pregnant women with anxiety tend to have low selfesteem. ${ }^{27-28}$ In relation to the above, it is noteworthy that the decreased levels of self-esteem may lead to the emergence of anxiety and thus decrease the quality of life of individuals who experience these mental changes. ${ }^{29}$ 
Still in this context, to better understand the relationship between these two variables, the literature shows that individuals with high levels of self-esteem tend to be in good mood, emotionally balanced, and able to build good relationships. On the other hand, the lower the levels of self-esteem, the greater the association with bad feelings, depression, and anxiety. This fact can be explained by the difficulties faced by individuals with low levels of self-esteem in dealing with the obstacles of everyday life. ${ }^{23}$

Given the above, it is important to emphasize that the gravidic-puerperal period is a phase where women are exposed to a high incidence of mental disorders, as previously mentioned. Thus, a multi-professional healthcare team is needed, primarily composed of nursing practitioners, to maintain or restore these women's mental health, assisting in decreasing their feelings of anxiety and increasing the levels of self-esteem experienced by them. ${ }^{30}$

It is worth mentioning that the present study faced some limitations. One of these limitations concerns the cross-sectional design, which meant that the cause-effect relationship of the results found could not be verified, in addition to the fact that the use of the odds ratio test in the cross-sectional study may present an overestimation of the effect on the crossings of the variables. However, the design was still relevant since it allowed the classification and association of independent variables with dependent variables.

Another limitation found was the difficulty in accessing the study population, due to geographic limitations and the small number of pregnant women, which influenced the sample size, due to the low adherence to prenatal care in the municipality where the research was conducted; however, the information was relevant for researching and understanding this phenomenon. Still, the lack of variables to assess social determinants, such as class, race and gender, was considered a limitation, due to a limitation of the instruments.

Therefore, it is suggested that longitudinal investigations should be carried out to address the issue analyzed in this study, in order to demonstrate the causal nexus and the cause- 
Assessment of anxiety and self-esteem experienced by women during pregnancy | 14

effect relationship between the feelings of anxiety and the changes in the levels of self-esteem experienced by women in the gestation period. In addition, it is suggested to carry out studies with other populations, with larger samples, as well as in other periods of the gravidic-puerperal cycle. It is also suggested to carry out experimental or quasi-experimental research in order to apply interventions to these women during the gestation period, in order to determine the mental changes that are caused by the changes resulting from pregnancy.

\section{Conclusion}

Through this study, it was possible to conclude that a large part (48.2\%) of women in the gestational period experienced feelings of anxiety, and that $81.1 \%$ of them experienced average levels of self-esteem. Some variables can influence the anxiety experienced by pregnant women, such as mood swings and the influence of physical changes during pregnancy. Women who experienced feelings of anxiety were three times more likely to experience changes in their self-esteem levels.

It is essential to take measures to prevent or mitigate the factors that facilitate mental changes during pregnancy, such as anxiety and decreased self-esteem. This is important so that women can face these changes and experience pregnancy with good physical and mental health.

It is believed that healthcare practitioners, including nursing staff, can raise awareness on this topic, aiming to provide integral assistance to women during the gestation period. Furthermore, it is important to take advantage of the moment to reinforce the bonds with the patients, with consequent improvement of the patient-practitioner bond and promote greater adherence to healthcare.

This research can bring advances to scientific knowledge and to the nursing field to support the development of actions such as continuous education and protocols, with strategies that aim to promote the humanization, integrality, and continuity of the care provided to pregnant women. This is important for reducing the feelings of anxiety and increasing the levels of self-esteem experienced by women throughout the gravidic-puerperal cycle. 
It is also emphasized that a present investigation can contribute to a improvement of prenatal care in the ESF, in addition to develop, in health professionals, a different perception regarding the mental health of pregnant women.

Given all the above in this study, especially with the results obtained, it is believed that health professionals, including those from nurses manage to sensitize themselves, subordinating comprehensive care to woman in the gestational period. As well as, seize the moment to reinforce the ties with women, with the consequent improvement of the patientprofessional bond and greater adherence to the health service

\section{Referências}

1. Silva MMJ, Lima GS, Monteiro JCS, Clapis MJ. Depression in pregnancy: risk factors associated with its occurrence. SMAD Rev Eletrônica Saúde Mental Álcool Drog. 2020;16(1):1-12. doi: https://dx.doi.org/10.11606/issn.1806-6976.smad.2020.153332

2. Organização Mundial da Saúde (OMS). Classificação dos transtornos mentais e de comportamentos da CID-10: descrições clínicas e diretrizes diagnósticas. Porto Alegre (RS): Artes Médicas; 2009.

3. Watson B, Fuller-Tyszkiewicz M, Broadbent J, Skouteris H. The meaning of body image experiences during the perinatal period: a systematic review of the qualitative literature. Body Image. 2015;14(10):10213. doi: https://doi.org/10.1016/j.bodyim.2015.04.005

4. Spindola T, Penha LH, Lapa AT, Cavalcanti ALS, Silva JMR, Santana RSC. Período pós-parto na ótica de mulheres atendidas em um hospital universitário. Enfermagem Foco [Internet]. 2017 [acesso em 2021 ago 19];8(1):42-6. Disponível em: http://revista.cofen.gov.br/index.php/enfermagem/article/download/847/364

5. Meireles JFF, Neves CM, Carvalho PHB, Ferreira MEC. Body image, eating attitudes, depressive symptoms, self-esteem and anxiety in pregnant women of Juiz de Fora, Minas Gerais, Brazil. Ciênc Saúde Colet. 2017;22(2):437-45. doi: https://doi.org/10.1590/1413-81232017222.23182015

6. Costa PF, Brito RS. Orientações ofertadas às puérperas no alojamento conjunto: revisão integrativa da literatura. Espaç Saúde [Internet]. 2016 [acesso em 2021 ago 19];17(2):237-45. Disponível em: https://www.researchgate.net/publication/312355717_Orientacoes_ofertadas_as_puerperas_no_alojament o_conjunto_revisao_integrativa_da_literatura

7. Pereira AS, Willhelm AR, Koller SH, Almeida RMM. Fatores de risco e proteção para tentativa de suicídio na adultez emergente. Ciênc Saúde Colet. 2018;23(11):3767-77. doi: https://dx.doi.org/10.1590/1413-812320182311.29112016 
Assessment of anxiety and self-esteem experienced by women during pregnancy | 16

8. Giardinelli L, Innocenti A, Benni L, Stefanini MC, Lino G, Lunardi C, et al. Depression and anxiety in perinatal period: prevalence and risk factors in an Italian sample. Arch Womens Ment Health. 2012;15(1):21-30. doi: https://doi.org/10.1007/s00737-011-0249-8

9. Botega NJ, Pondé MP, Medeiros PG, Lima MG, Guerreiro CAM. Validação da escala hospitalar de ansiedade e depressão (HAD) em pacientes epilépticos ambulatoriais. J Bras Psiquiatr. 1998;47(6):285-9.

10. Dini GM, Quaresma MR, Ferreira LM. Adaptação cultural e validação da versão brasileira da Escala de Auto-estima de Rosenberg. Rev Bras Cir Plást [Internet]. 2004 [cited 2021 Aug 19];19(1):41-52. Available from: http:/www.rbcp.org.br/details/322/pt-BR/adaptacao-cultural-e-validacao-da-versaobrasileira-da-escala-de-auto-estima-de-rosenberg

11. Schwarz G. Estimating the dimension of a model. Ann Stat. 1978;6:461-4.

12. Costa DO, Souza FIS, Pedroso GC, Strufaldi MWL. Transtornos mentais na gravidez e condições do recém-nascido: estudo longitudinal com gestantes assistidas na atenção básica. Ciênc Saúde Colet. 2018;23(3):691-700. doi: https://dx.doi.org/10.1590/1413-81232018233.27772015

13. Silva MMJ, Leite EPRC, Nogueira DA, Clapis MJ. Depression in pregnancy: prevalence and associated factors. Invest Educ Enferm. 2016;34(2):342-50. doi: https://doi.org/10.17533/udea.iee.v34n2a14

14. Schiavo RA, Rodrigues OMPR, Perosa GB. Variables associated with gestational anxiety in primigravidas and multigravidas. Trends Psychol. 2018;26(4):2091-104. doi: https://doi.org/10.9788/TP2018.4-14En

15. Vega Gonzales E, Guerrero Rosa A, Guzmán Castillo B, Huamaní Morales E, Herrera Chenett G. Ansiedade y depression en gestantes adolescentes en un hospital de Lima, Peru. Rev Int Salud Materno Fetal [Internet]. 2019 [acceso 2021 ago 19];4(4):3-7. Disponible en: http://ojs.revistamaternofetal.com/index.php/RISMF/article/view/107/110

16. Lucci TK, Otta E, David VF, Chelini MM. Maternal depression and offspring's cortisol concentrations in a Brazilian sample. Psico. 2016;47(2):140-7. doi: https://dx.doi.org/10.15448/19808623.2016.2.23655

17. Lameira NRO, Santos MPQ, Rodrigues LS, Souza TMS, Garcez JCD, Araujo MAG, et al. Boas práticas de enfermagem voltadas à gravidez na adolescência: relato de experiência. Rev Eletrônica Acervo Saúde. 2020;41(Suppl):e2300. doi: https://doi.org/10.25248/reas.e2300.2020

18. Krob AD, Godoy J, Leite KP, Mori SG. Depressão na gestação e no pós-parto e a responsividade materna nesse contexto. Rev Psicol Saúde. 2017;9(3):3-16. doi: https://dx.doi.org/10.20435/pssa.v9i3.565

19. Lima MOP, Tsunechiro MA, Bonadio IC, Murata M. Sintomas depressivos na gestação e fatores associados: estudo longitudinal. Acta Paul Enferm. 2017;30(1):39-46. doi: https://dx.doi.org/10.1590/19820194201700007

20. Yussuf ASM, Tang L, Binns CW, Lee AH. Prevalence of antenatal depressive symptoms among women in Sabah, Malaysia. J Matern Fetal Neonatal Med. 2016;29(7):1170-4. doi: https://doi.org/10.3109/14767058.2015.1039506 
21. Moimaz SAS, Rocha NB, Garbin CAS, Rovida TA, Saliba NA. Factors affecting intention to breastfeed of a group of Brazilian childbearing women. Women Birth. 2017;30(2):e119-24. doi: https://doi.org/10.1016/j.wombi.2016.10.004

22. Meireles JFF, Neves CM, Carvalho PHB, Ferreira MEC. Imagem corporal de gestantes: associação com variáveis sociodemográficas, antropométricas e obstétricas. Rev Bras Ginecol Obstet. 2015;37(7):31924. doi: https://dx.doi.org/10.1590/S0100-720320150005388

23. Pinheiro TA, Piovezan NM, Batista HHV, Muner LC. Relação dos procedimentos estéticos com satisfação da autoimagem corporal e autoestima de mulheres. Rev Cathedral [Internet]. 2020 [acesso em 2021 ago 19];2(1):1-31. Disponível em: http://cathedral.ojs.galoa.com.br/index.php/cathedral/article/view/106

24. Damacena LCA, Pinheiro DCA, Mattos JGS, Gomes NS. Gestação na adolescência e autoestima. Rev Enferm Atenção Saúde [Internet]. 2018 [cited 2021 Aug 19];7(3):39-49. Available from: http://seer.uftm.edu.br/revistaeletronica/index.php/enfer/article/view/2884

25. Morales J, Basilio M, Candia-Zambrano C. Violencia y autoestima en gestantes de un distrito del Callao. Health Care Glob Health [Internet]. 2019 [acesso em 2021 ago 19];3(2):75-0 Disponível em: http://52.37.22.248/index.php/hgh/article/view/52

26. Gomes FCS, Aragão FBA, Serra LLL, Chein MBC, Santos JPF, Santos LMR, et al. Relação entre o estresse e a autoestima de gestantes durante o pré-natal. Medicina (Ribeirão Preto). 2020;53(1):27-34. doi: https://doi.org/10.11606/issn.2176-7262.v53i1p27-34

27. Bai G, Raat H, Jaddoe WV, Mautner E, Korfage IJ. Trajectories and predictors of women's health related quality of life during pregnancy: a large longitudinal cohort study. PloS One. 2018;13(4):e0194999. doi: https://doi.org/10.1371/journal.pone.0194999

28. Asselmann E, Kunas SL, Wittchen HU, Martini J. Maternal personality, social support, and changes in depressive, anxiety, and stress symptoms during pregnancy and after delivery: a prospectivelongitudinal study. PLoS One. 2020;15(8):e0237609. doi: https://doi.org/10.1371/journal.pone.0237609

29. Nguyen DT, Wright EP, Dedding C, Pham TT, Bunders J. Low self-esteem and its association with anxiety, depression, and suicidal ideation in Vietnamese secondary school students: a cross-sectional study. Front Psychiatry. 2019;10(698). doi: https://doi.org/10.3389/fpsyt.2019.00698

30. Rodrigues ARM, Dantas SLC, Pereira AMM, Silveira MAM, Rodrigues DP. Gravidez de alto risco: Análise dos determinantes de saúde. Sanare (Sobral) [Internet]. 2017 [acesso em 2021 ago 19];16(01):23-8. Disponível em: https://sanare.emnuvens.com.br/sanare/article/view/1135

Scientific Editor: Tania Solange Bosi de Souza Magnago

Associated Editor: Graciela Dutra Sehnem 
Assessment of anxiety and self-esteem experienced by women during pregnancy | 18

Support/ Acknowlegement: This task was fulfilled with the support and Coordination of Higher Education Improvement Personnel Brazil (CAPES) - Funding Code 001

\section{Corresponding Author}

Nathália Gianini Nery

E-mail: nathaliagianininery@gmail.com

Address: Rua Petra Gago Munhoz, 191, Jardim Boa Esperança

ZIP Code: $37135-124$

\section{Authorship contributions}

\section{1 - Nathália Gianini Nery}

Conception or design of the study/research; analysis and/or interpretation of data and final review with critical and intellectual participation

\section{2 - Patrícia Mônica Ribeiro}

Analysis and/or interpretation of data and final review with critical and intellectual participation

\section{3 - Eliana Peres Rocha Carvalho Leite}

Analysis and/or interpretation of data and final review with critical and intellectual participation

\section{4 - Denismar Alves Nogueira}

Conception or design of the study/research; analysis and/or interpretation of data.

\section{5 - Sérgio Valverde Marques dos Santos}

Conception or design of the study/research; analysis and/or interpretation of data and final review with critical and intellectual participation

\section{6 - Fábio de Souza Terra}

Conception or design of the study/research; analysis and/or interpretation of data and final review with critical and intellectual participation

\section{How to cite this Article}

Nery NG, Ribeiro PM, Leite EPRC, Nogueira DA, Santos SVM, Terra FS. Assessment of anxiety and self-esteem experienced by women during pregnancy. Rev. Enferm. UFSM. 2021 [Accessed in: Year Month Day]; vol.11 e71: 118. DOI: https://doi.org/10.5902/2179769265433 